\title{
REFRAMING IDENTITIES IN THE MOVE: A TALE OF EMPOWERMENT, AGENCY AND AUTONOMY
}

\section{A RECONSTRUÇÃO DAS IDENTIDADES EM MOVIMENTO: UM CASO DE EMPODERAMENTO, AGÊNCIA E AUTONOMIA}

\author{
Christine Nicolaides* \\ Renata Archanjo**
}

\begin{abstract}
Transnational movements raised by globalization to a status of normality, let alone to absolute necessity, have reshaped the world and social practices (VERTOVEC, 2007; WEI \& HUA, 2013). As a social practice, language dimension acquires a renewed importance in the way people use and consume languages functioning as an agent in the exercise of social and political power. Language ideologies, whether individual or socioculturally constructed, may be a source of empowerment or, conversely, disempowerment, forging asymmetries in the way people consume languages. Thus, the pursuit of autonomy in language learning with the combination of its technical, psychological, sociocultural and political dimensions constitutes a space for (inter)personal emancipation and social transformation. Our theoretical framework emphasizes the collective aspects of learner autonomy, based on the sociocultural autonomy concept (OXFORD, 2003). Drawing on Bakhtin's $(1929 / 2006 ; 1981)$ and Vygotsky's (1991) contributions used as groundwork for research in learner autonomy and in consonance with ideas of fluid and hybrid identities (HALL, 1992; BAUMAN, 2005; MOITA LOPES, 2006), this paper discusses agency, empowerment and identity through sociocultural autonomy development in multicultural environments. This chapter, then, is an attempt to show issues of empowerment, autonomy and agency being processed across real-life social language practices. Its findings and results come from two research projects conducted by the authors in two different contexts but related to the same research interest. Both projects aimed to analyze language learning autonomy, agency and empowerment in the continuous process of learners (re)constructing their identities, while learning a second language. Data generation was based on interviews with two speakers of Brazilian Portuguese and learners of English as an additional language, while taking part in exchange programs for international mobility - one of them in the U.S and another one in Australia. Results show that both participants seem to reframe their multiple identities, so that they can adapt and readapt themselves to the new communities of practice (COP), in which they have emerged. Factors like agency, empowerment and sociocultural autonomy seem to be essential and decisive in this process of reframing identities.
\end{abstract}

Keywords: identity; sociocultural autonomy; language practices.

\footnotetext{
* Universidade Federal do Rio de Janeiro (UFRJ), Rio de Janeiro, RJ, Brasil. christine.nicolaides@ letras.ufri.br

** Universidade Federal do Rio Grande do Norte (UFRN), Natal, RN, Brasil. renaarchanjo@gmail.com
} 


\section{RESUMO}

Movimentos transnacionais alçados pela globalização a um nível de normalidade, para não de dizer de absoluta necessidade, reconstruíram o mundo e suas práticas sociais. Como prática social, as dimensões da língua adquirem também uma nova importância na forma como as pessoas usam e consomem línguas funcionando, assim, como agentes no exercício do poder político e social. As ideologias linguísticas, sejam elas construídas de forma individual ou social podem ser uma fonte de empoderamento ou, por outro lado, de desempoderamento, forjando assimetrias na forma como as pessoas consomem línguas. Desta forma, a busca pela autonomia na aprendizagem de línguas com a combinação de suas dimensões técnica, psicológica, sociocultural e política constituem um espaço (inter)pessoal de emancipação e de transformação social. O viés teórico deste artigo enfatiza os aspectos sociais, no lugar dos individuais, da autonomia do aprendiz, com base na concepção da chamada autonomia sociocultural (OXFORD, 2003). Lançando mão das contribuições de Bakhtin (1929/2006; 1981) e Vygotsky (1991), utilizadas como bases teóricas para este trabalho e em consonância com as ideias de identidades fluídas e híbridas (HALL, 1992; BAUMAN, 2005; MOITA LOPES, 2006), discute-se agência, empoderamento e identidade por meio do desenvolvimento da autonomia sociocultural em ambientes multiculturais. Este artigo então é uma tentativa de mostrar questões de empoderamento, autonomia e agência reveladas em práticas sociais e de linguagem reais em resultados obtidos em dois projetos de pesquisa conduzidos separadamente pelas autoras em dois contextos diferentes, mas relacionados com o mesmo interesse de pesquisa. Em outras palavras, ambos projetos almejaram analisar autonomia de aprendizes de língua, agência e empoderamento no processo contínuo de reconstrução de identidades dos aprendizes ao aprenderem uma segunda língua. Este artigo é o resultado de dois projetos de pesquisa conduzidos separadamente pelas autoras deste trabalho, mas relacionados ao mesmo interesse de pesquisa, ou seja, a autonomia na aprendizagem de língua e agência em um constante processo de construção de identidades. A geração de dados foi baseada em entrevistas com duas falantes de português brasileiro e aprendizes de inglês como língua adicional, enquanto faziam programa de intercâmbio nos E.U.A. e na Austrália. Os resultados mostram que ambas participantes parecem reconstruir suas múltiplas identidades, de forma a se adaptarem e readaptarem às novas comunidades de prática - COP nas quais elas emergem. Fatores como agência, empoderamento e autonomia sociocultural parecem ser essenciais e decisivos neste processo de reconstrução de identidades.

Palavras-chave: identidade; autonomia sociocultural ${ }_{i}$ práticas discursivas.

\section{INTRODUCTION}

"Who in the world am I? Ah, that's the great puzzle." Lewis Carroll. Alice in Wonderland. "I knew who I was this morning, but I've changed a few times since then." Lewis Carroll. Alice's adventures in Wonderland \& Through the looking glass.

This paper is about identity. It explores how identities are (re)framed, (re) positioned and (re)constructed through empowerment, agency and autonomy. Identity matters, and may reconfigure quite a few times during life. The extent 
of these changes will depend on time, place, and on specific historical, social and material circumstances (WOODWARD, 2002). According to Bauman (BAUMAN, 2004, p.12), awareness of "having an identity will not occur to people as long as belonging remains their fate, a condition with no alternative." Indeed, for some, "identity only becomes an issue when it is in crisis" (MERCER, 1990, p. 4), which in many cases is what challenges an established identity and triggers a necessary investment in a process of change. Movement precipitates this process, since placements and displacements involve natural changes, whether material or subjective. Lately, due in large part to globalization, people's lives are materially and subjectively affected by global and transnational movements and processes (WEI \& HUA, 2013). The consequent emergence of transnational identities is an expected outcome (De FINA, 2016).

Central to this movement is the role of language: the element through which identities are built, negotiated and ultimately transformed (HALL, 1992; BAUMAN, 2005; MOITA LOPES, 2006). The centrality of language lies not only in the fact that it serves as a medium of communication, but most importantly because it is through language that "a person understands his or her relationship to the world, how that relationship is structured across time and space, and how the person understands possibilities for the future" (NORTON, 2013:4). However, language, as a social and historical practice (MAKONI \& PENNYCOOK, 2007) and a political and ideological construct (BLOMMAERT, 2006) does not stand for a homogeneous or undisputed translator of individual subjectivities. Rather, it is a powerful indexer of how individuals position themselves as social and historical subjects, performing identities that ultimately dictate who they are, where they come from, what they believe in and what they want to become. Language functions as a well-marked element of integration or disruption in social spaces and communities of practice (COPs).

In this paper, identity is discussed in reference to language practices through which interactions are instantiated and negotiated. The main concern is to discuss issues related to empowerment, autonomy and agency as they emerged in personal narratives gathered from two research projects. The projects in question were conducted separately by the authors in two different contexts but related to the same research interest. Both projects aimed to analyze language learning autonomy, agency and empowerment in the continuous process of learners (re)constructing their identities, while learning a second language.

The two narratives presented as case studies illustrate how the search for a legitimate voice through language learning within the COPs in which the 
participants have emerged in, have led to the reframing of their identities. This transformation process could not be more representative of engagement (WENGER, 1998), investment (NORTON, 2000; 2010; 2013; MCKINNEY \& NORTON, 2008), agency (NORTON, 2012; 2016) and empowerment (BOURDIEU, 1991; WEEDON, 1997) since the learning experience of our participants, while transformative of what they were and what they have become, was also an identity experience. In what follows, we will present the framework used to support our claims, pointing out the learning experience in the move as a decisive factor in the emergence of new identities.

In what follows, the article will address the theoretical stands on how we view language, as well as important concepts for our line of thought around COP and imagined communities, agency and empowerment, and how they all relate to learner autonomy. In the second session, we explain how data were generated in both research projects and the categories chosen for our analysis. Finally, we end the article with some final considerations and future perspectives in the matters approached throughout the paper.

\section{THEORETICAL GROUNDS}

\subsection{Language}

Bakhtin's theory of language $(1929 / 2006) ; 1981)$ argues that languages are social and ideological constructions with no independent existence outside the use that speakers in interaction with others may do. Makoni and Pennycook (2006, p. 2) concur with that line of reasoning while arguing that "languages do not exist as real entities in the world and neither do they emerge or represent real environments; they are, by contrast, the inventions of social, cultural and political movements". Languages are thus human constructions used to attribute meaning to human practices, to position oneself, to negotiate social, cultural and political spaces, and sometimes to resist all of that. Languages are instruments of action and, as such, instruments of power since it is through language practices that power circulates, promoting either inclusion or exclusion according to different social conditions.

Indeed, people do not speak, or write, or paint, or use any imagined form of symbolic resource just to communicate but to be heard, to express points of view, to be obeyed, to gain respect, to accuse, to be loved, to disgrace, and so forth. As Bourdieu points out, the legitimacy of the language is directly linked to "the right to speak", which by the speech of voices of authority imply "the power to impose 
reception" (BOURDIEU, 1977, p. 648). It is important to stress that language practices, here understood as any symbolic system interplaying in the process of meaning making in social interactions, are thus not neutral. It always sets forth a valued position embedded in ideological beliefs entailing thus relations of power. Language and ideology constitute one another and since they foreground all human interactions, they also play an essential role in shaping identities.

Complementary to that, language learning as an essential resource to ensure communication and thus recognition and legitimacy brings an "added value" (DUCHÊNE \& HELLER, 2012) to the ongoing process of identity construction. Indeed, language education as a linguistic capital (BOURDIEU, 1991) is decisive in helping to reshape identity, transcending the limits established by the original condition of immigrant, foreigner and non-native speaker. As we will see from this project's sample population, learning and improving their language knowledge, far beyond the acquired skills and competence, have led our participants to build a positive integrated position and an identity of their own.

\subsection{Community of practices and Imagined communities}

Connected to the well-known idea of community of practice COP, understood as groups of people who share a common interest for something through which they do and learn while interacting on a regular basis (LAVE \& WENGER, 1991) we also bring into light the concept of imagined communities. Anderson was the first scholar who came up with this concept. As the author exemplifies:

An American will never meet, or even know the names of more than a handful of his $240,000,00$-odd fellow-Americans. He has no idea of what they are up to at any one time. But he has complete confidence in their steady, anonymous, simultaneous activity. (ANDERSON, 1983/2006, p. 26)

In the same line of thought, Norton states that imagined community "refers to groups of people, not immediately tangible and accessible, with whom we connect through the power of the imagination". (NORTON, 2012, p.8). According to the author, even for people who have never actually become physically part of their imagined community, this concept can be as strong as the one of an actual community of practice. Imagination is at the same time an individual and a social process that allows us to frame possibilities and idealize ways to engage into targeted COPs. Through this process, which represents at the same time a desire and a goal, people are able to invest time and energy in order to multiply forms of participation into different COPs (PAVLENKO \& NORTON, 2007). Again, 
some excerpts from this paper will show the relevance of the concept of imagined communities for these learners, who dream of becoming part of English-speaking communities and try to live as much of the culture of these new COPs as they can: even before they become part of them. These imagined communities may serve as a motivational factor to learn the target language, as much as they can bring frustrations and disappointments.

\subsection{Agency and empowerment}

When it comes to agency, we advocate the idea that it is intertwined with one of empowerment. As empowerment, we take Hale's words in which he states that "learners will take 'ownership' of the language, resulting in a concomitant increase in learner autonomy and feelings of empowerment" (HALE, 2012). Here the concept of empowerment is not only related to agency itself, but also to the one of becoming autonomous and capable of making choices throughout his or her path as a learner of a new language and with it, acquiring new social practices.

As for agency itself, we apply the definition proposed by Hunter \& Cooke (2007), understood as "the ability to act with initiative and effect in a socially constructed world". This particularly concerns learners of an additional language such as English, which is seen as a bridge to empowerment, through the access of new COPs. In turn, considering members of a community always act in a socially constructed world (FAIRLOUGH, 2001), these new members will reshape their identities through time, as their social language practices as well as their roles in the COP changes. Again, this will only be possible if these learners feel they are empowered to do so, and if members of that community allow them to so. Learners of a language who feel they are not accepted for their nonnative variety of the language, for instance, may feel discouraged and are probably going to find more difficulties in improving their communication skills in the additional language. On the other hand, obstacles like these might also be means to empowerment and ownership of the language as some of our data show in this article.

\subsection{Autonomy}

Last but not least, we connect the concepts of agency, empowerment and imagined communities with the one of autonomy. Here, a collective idea of autonomy takes over the individual one. More specifically, four elements in Oxford's model of learner autonomy (OXFORD, 2003) play a relevant role: context, agency, motivation, and learning strategies. The author constructs her 
arguments based on the idea that although individual abilities towards a new language are important to be developed while developing learner autonomy, also the sociocultural perspective, based on Vygotsky's sociocultural theory, becomes of paramount importance. Oxford then divides the sociocultural perspective of autonomy into two versions - Sociocultural Autonomy I and Sociocultural Autonomy II. The first one would refer to the interaction between the less and the more experienced learner. Sociocultural Autonomy II then would be the legitimation of the newcomer in the COP itself.

The sociocultural aspect of autonomy proposed by Norton, of course, is based on one of probably the biggest contributions of Vygotsky (1985), in which he states that learning is always mediated through something or someone - that we do not act directly in the world, but through mediation. For Vygotsky (1985), although language and thought are separate entities, they are intertwined and necessary for the comprehension of human intellectual development. Speech is not a direct expression of thoughts, but one helps the other to be shaped and constructed throughout the formation and transformation of our personalities. It is through language that the child, as well as the adult, is constantly organizing and reorganizing thoughts, as he or she interacts with other human beings. This way, interaction becomes an essential factor to be considered when analyzing language from a Vygotskian perspective, as it will be shown in this paper through the data presented. Participants seem to be in constant adaptation and readaptation of their identities as they interact through new language practices in their communities, moving from peripheral roles to more central ones.

Considering a COP, there will be members already acknowledged as actual members of that community and the ones who are less acknowledged, either because they are younger or because they do not master yet the social practices adopted in the group. As mentioned before, Oxford then divides sociocultural autonomy it in two versions. Sociocultural Autonomy I would be the one related to the interaction between the less and the more experienced learner through social practices, including language ones. As for Sociocultural Autonomy II, autonomy is not the target itself, but the desire of the new members to be part of that group. As they become more familiar with new social practices, they start moving from a less peripheral positions in the community to occupy more central ones. In Oxford's own words:

In sum, both the Sociocultural I and Sociocultural II categories contribute ideas concerning mediated, meaningful, situated learning that involves a sense of agency. Motivation is important in both Sociocultural I and II, but in Sociocultural II its characterization is particularly insightful: 
investment in the imagined community. Learning strategies play somewhat different, but still significant roles in the two aspects of the sociocultural perspective. (OXFORD, 2003, p. 88)

Concerning the learning of a new language, it is possible to connect it to these two concepts of sociocultural autonomy proposed by Oxford Learners of a new language, motivated by their imagined communities, slowly make efforts to be accepted in that COP, as they master their new language practices through interaction with members who are linguistically more proficient. Whether they find obstacles to have access to these social practices is another issue, which will be addressed throughout this paper. This way, Norton's contribution to the area of learner autonomy has become a landmark, which questions the emphasis on the individual rather than on collective aspects of autonomy, and it is fully adopted in this study.

In a nutshell, when it comes to identity related to language learning, as posed by Norton (2012), binary concepts which used to be adopted by researchers in the second language acquisition field, do not seem to convey the complexity of factors that language practices and language learning involve. In next figure, based on Nicolaides (2017) representation of how sociocultural autonomy develops Nicolaides (2017), we try to show how this complex net of factors might work together.

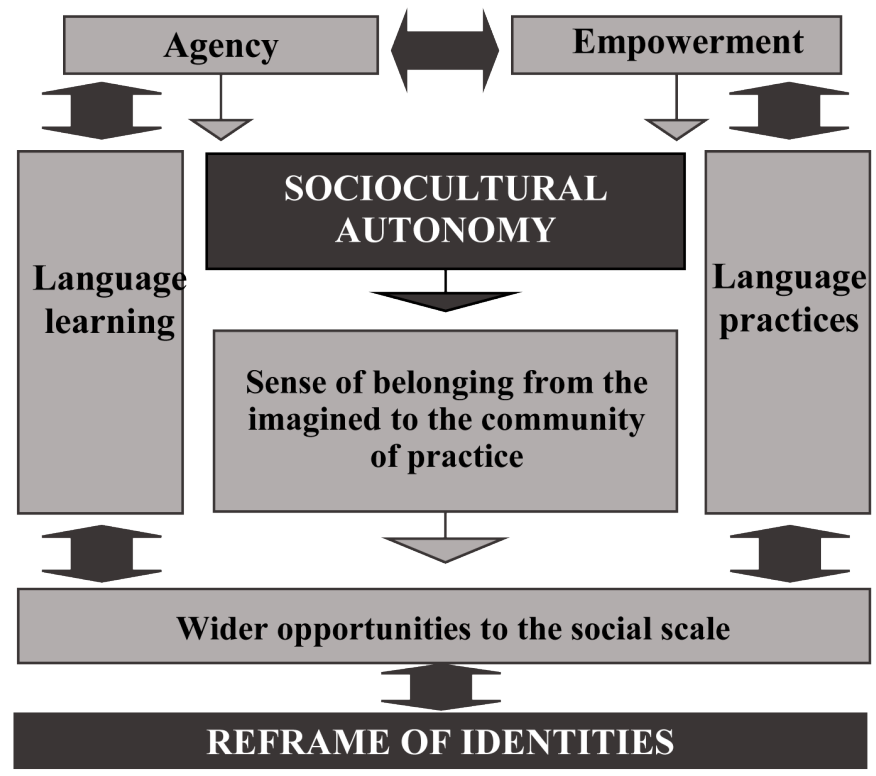

Figure 1. Relationship between agency, empowerment, sociocultural autonomy, language learning, language practices, and identities. (Adapted by the authors from NICOLAIDES, 2017) 
From our view, and what we illustrate throughout these studies, our participants act on a social world as they empower themselves through language practices and language learning. As learners of this target language, they see themselves as part of an imagined community, even if they have not yet been to a country where they language is spoken or have never spoken to a native speaker of that language yet.

As time goes by, and they have the chance to actually be in contact with the real COP, they seem to constantly reframe their identities, negotiating who they are and how they relate to the world, as they are legitimated (or not) by their peers in their community of practice. Clearly, this legitimation leads to more opportunities for language practices and, consequently, language learning. As this legitimation by members of the community happens, naturally, these new members start to also access wider opportunities in the social scale. Finally, in this deep and challenging net of factors, learners of the new language seem to develop their sociocultural autonomy, which involves much more than individual aspects of the learner only, but a whole array of factors embedded in collective aspects of a community of practice.

\section{DATA GENERATION}

This paper results from a joint symposium on the role of agency and autonomy in the learning of an additional language presented at the AILA ${ }^{1}$ World Congress Rio, 2017. Both authors brought data from their separate research projects to discuss convergent impressions and outcomes as it will be depicted as follows. In spite of coming from two different research projects, the concurrence of findings drove us to present, in a writing version, how these students, although through different paths, go through similar obstacles while learning the new language and are constantly reframing their identities.

The first set of data comes from a corpus of five native speakers of Brazilian Portuguese language, immigrants and learners of English as an additional language. At the time, one of the researchers was in the U.S as visiting scholar at a Master TESOL program, when she developed the research "Agency and Empowerment towards the Pursuit of Sociocultural Autonomy in Language Learning in a Multicultural Environment", in 2016. During her study, students of English as a

1. International Association of Applied Linguistics. 
second language were interviewed ${ }^{2}$, excerpts which were audio recorded and later on transcribed for analysis. She also kept a reflexive diary with her main impressions about her interactions with these students. Out of these students, data based on BETTY $^{3}$ were selected to this article. While being interviewed, BETTY was in her late twenties and considered herself an "immigrant", although she was in the U.S through an Aupair ${ }^{4}$ program for a period of only two years (NICOLAIDES, 2017). In Brazil, BETTY was in the last year of her undergraduate course in Business Administration of well-known public university. Whereas in the U.S., she was hosted at an "American traditional upper-middle class family", as herself has defined. BETTY described her English proficiency level as advanced, when she started her experience as an aupair, despite the difficulties she faced along her stay in the host country concerning linguistic issues, as it is reported along this article.

The second set of data comes from a corpus of ten university college students, native speakers of Brazilian Portuguese, interviewed between 2015 and 2016, while participating in the international mobility program Science without Borders ${ }^{5}$ $(\mathrm{SwB})$. Data were generated during a Post-doctoral fellowship in the UK where the researcher carried out a project entitled: "International mobility and emerging multilingual and multicultural practices: focus on the Brazilian governmental program SwB (ARCHANJO, 2015, 2016, 2017). Among the research participants, JULIA $^{6}$ was the one selected to contribute on this article due to the richness of her own story and the intertwined relationship between her path in learning and developing an English language competence and the impacts of that linguistic capital in reshaping her own identity as a student and as a future professional. At the time of the interview in 2016, JULIA was returning to Brazil after an eighteenmonth period of academic mobility lived in Australia.

2. Interviews with both participants were generated originally in Portuguese and translated to English by the authors for the purpose of this article.

3. Pseudonym given to the participant to protect her identity.

4. An au pair is an unmarried young adult aged 18 to 30 years, who has no children and travels to a foreign country for a defined period of time to live with a host family. The au pair is considered as a full member of the family during the entire stay. As such, he or she helps the family with childcare and can be asked to assume some light household tasks. In return, the host family provides free board and lodging, as well as pocket money. However, the au pair is neither a housekeeper, nor a nanny. Accessed at https://www.aupairworld.com/en/au_pair/au_pair.

5. Science without Borders is a large-scale nationwide scholarship program primarily funded by the Brazilian federal government. The program seeks to strengthen and expand the initiatives of science and technology, innovation and competitiveness through international mobility of undergraduate and graduate students and researchers. http://www.cienciasemfronteiras.gov.br/web/csf-eng/faq

6. Also, a pseudonym to protect the participant's identity. 
In both research design, data were generated through discourse-based interviews and analyzed from a discursive perspective. The interviews were semistructured, so that we had a set of questions designed for the interview as a guide, but there was freedom for both interviewer and interviewed to address other questions and comments. BETTY's interview was conducted on a face to face encounter while JULIA's was made by Skype. Both interviews have been recorded and posteriorly transcribed. The two case studies used to illustrate this paper intend to shed light on the process of reframing identities while in the move and through the performativity of an additional language. Both case studies point out to the participant's awareness in having transformed and reshaped their identities in a way they are not the same when they return to their original COPs.

\section{DATA ANALYSIS}

In accordance with the concepts presented in the previous sections, the data are presented through the following categories of analysis: imagined communities and COPs; agency and empowerment and different sites, different identities. The categories actually emerged from the data themselves, and we specifically established and chose them once we realized how similar and convergent the obstacles and perceptions of both participants were. All these categories are intertwined with language and identity formation and sociocultural autonomy development, as it has been previously argued in this paper.

\subsection{Imagined Communities and Communities of Practice}

For many learners of a foreign language, particularly when they are already immersed in the foreign country, it is necessary to reconcile two powerful realities: the community of imagination, the desirable community, the one that enhances their possibilities for the future and strengthen their identity. Alongside the imagined community, the community of practices set out the boundaries of real engagement and participation in social interactions. Investment (NORTON, 2010, 2012 , 2013), thus is essential to ensure this engagement and to foster reframing identities "which change across time and space, and which are constructed on the basis of the socially given, and the individually struggled-for" (NORTON \& TOOHEY, 2011, p.420). As her imagined community, BETTY describes the U.S. as the something she has always dreamed becoming part of it. We can feel her emotions through her words while she describes this desire: 
BETTY: I have always been in love with the United States. I bad that obsession that... that I couldn't explain why.

CHRISTINE: Hum...

BETTY: But all my friends said 'wow, you bave always bad this dream to live overseas and etc., and then financially, what was viable, for me, for my family, it was some kind of exchange program in which I would be paid for.

BETTY: So, family, this family in which I am actually, chose me because of my English, because the children were seven, six years old, and they wanted someone who already had. .

CHRISTINE: Are they American?

BETTY: Yes, they are American.

CHRISTINE: Ok, bum, bum. So, it was their requirement that...

BETTY: Yes.

CHRISTINE: Had...

BETTY: Yes...

Her disappointment of being acknowledged as a member of an actual member of this community though comes almost immediately after she arrives in this new family:

BETTY: No, there is no exchange. Because... actually the program is like a cultural exchange...

CHRISTINE: Exactly.

BETTY: You are going to be the 'big sister' of the child.

CHRISTINE: That was I bad in mind.

BETTY: This was what I thought as well, and I guarantee that $80 \%$ of the girls think like this, for me it was a shock, when I arrived, to realize I lived with people who treated me as a maid, that only saw me as a maid.

As we can read in BETTY's words, she is quite disappointed, dishearten and even feeling deceived for what was promised for her in this experience as an aupair. It seems BETTY created expectations, in which she was going to be 'part of the American life', part of that American family. The moment she is hosted at this family, and she is treated only as a maid, and only an employee-employer relationship is established, it is like all her dreams and expectations fall apart.

The event with BETTY can be related to Norton's concept of 'imagined communities', in which she states "... in imagining ourselves bonded with our fellow citizens across time and space, we can feel a sense of community with people we have not yet met, but perhaps hope to meet one day." (NORTON, 2012, p.8). Further, the author affirms, "These imagined communities are no less real than the ones in which learners have daily engagement and might even have a stronger impact on their current actions and investment." (NORTON, 2012, p.8) In other words, a gap is constructed between BETTY's imagined community and her actual $\mathrm{COP}$, and this has a huge impact in her experience as a language learner, especially as a member of this new community. 
Differently from BETTY, JULIA had not dreamt to go to an English-speaking country when she applied to the SwB program. As she explains:

JULIA: I left Brazil without speaking a word in English. I have always wanted to learn English but since I could never afford to pay for an English course, nor I had the chance to win the raffle for a free English course in this prestigious public High School, I thought then that Portugal would be a good choice for me because even if I do not learn a language, but it will be an experience, so whatever experience that I may have, it will worth be of it.

JULIA was not developing expectations based on an English imagined community because she was happy enough with the chance to have an international experience without being challenged by a different language than her own. Interestingly, life happens to have its own operation mode and due to a political change in the SwB's Program, all students applying to Portugal that year had been redirected to other countries, all English-speaking countries. That is when JULIA, to fulfill her plans to experience an international academic exchange, had to confront with a totally different community of practice.

\footnotetext{
JULIA: When I first arrived, I stayed at the University of Sydney (...) They bad done an agreement, students who did not have intermediate level of English, they studied a little bit of grammar, but they started doing a kind of intensive for IELTS. But as I was considered zero, I started with basic English.

The course started in August and went until January. In February, we had to do the IELTS (...) while the others were training to the IELTS, I was trying to learn the language to be able to stay there. In the first month, all I could do was listen: JULIA do this... JULIA do that... I could only gaze.

I also asked teachers for belp. (...) I used to practice at home everything what I bad to tell them because I didn't know what to say. I used to say: look, I don't know, ok? I came bere from zero. And they used to ask me: bow come? And I... well, the government offered me a special situation and since they offered me that, I'll take it. So bere I am, and I want to learn. The first month was... Well... I can tell you, it was pretty hard, because I tried, I mean, I tried to study but it doesn't work (...). It was only in the second month that I started to say some things.
}

As much as we can rely on the benefits of the unexpected changes imposed by the SwB's Program, for JULIA, to be thrown into a place where she was not prepared to be, has demanded a great deal of investment just to secure, in the first place, the right to remain where she was. Her first struggle then was to prove that she would be capable to take a place into that COP. Drawing on Norton's words "The construct of investment seeks to make a meaningful connection between a learner's desire and commitment to learn a language, and the language practices" (NORTON \& TOOHEY, 2011, p.415). The investment in learning English marked an identity position in the sense that JULIA was adapting and trying to enhance her chances to get access to a whole new world that she would think out of her reach a few months before. To position herself as a language learner allowed JULIA to 
reshape her identity based on the socio-cultural settings in which she had emerged in and engaged with.

\subsection{Agency and Empowerment}

Assuming with Norton and Toohey (2011, p.419) that "learning is a social process in which culturally and historically situated participants engage in culturally valued activities, using cultural tools" it became clear that JULIA was deliberately taking upon herself the responsibility for her actions and commitments.

\footnotetext{
JULIA: I didn't know bow to speak but I would go for it. So, in the beginning, I bad this teacher, be suffered a lot trying to teach me and notbing came out. He used to give me books, tell me to listen to the radio... In the second month, I bought the course manuals, my computer and then I started to listen to music, to see movies... I couldn't understand a thing, but I watched them. I started to go to Masses, this kind of thing that would belp me to get used with the sound of the language

At the classes, I didn't have any trouble to follow because my problem was to learn English. Once I've learned to speak English ..., and I speak a lot, right or wrong, I was always speaking. When I was with others in the same situation as mine, like a Chinese or an Arab person, that's when I used to speak more, because everybody was making mistakes and speaking wrong, we understood each other.
}

Agency for JULIA was not merely a matter of being a good student and speak whenever she had a chance to practice the language. Agency was, despite structural conditions, limited materials and some social interactions, a matter of struggling to situate herself in the context where she was living. Agency was her chance to feel empowered in a context where, from the starting point, she was considered in disadvantage regarding the others. JULIA's attitude is crystal through her words:

JULIA: In my classes there were only Australians or people from, like, Canada or New Zealand and their English was a perfect English, very beautiful. Once in a while I was ashamed, but I kept thinking: while they are speaking their English, I am bere with my "broken" English, but I am bere, I am managing (...)

Drawing on JULIA's testimony we can see power being attributed to the ownership of English as a native language. However, JULIA reverted her unequal status by empowering herself with her own linguistic capital whether native or nonnative, good or bad English. As "broken" as she would possibly name her language competence, it was through that competence that she was accomplishing her goals and there was nothing wrong with that.

On BETTY's side, as time goes by, we can perceive that although still dishearten for not having her initial expectations fulfilled, she seems to somehow recover her strengths and empower herself through the English language. She describes herself now as someone who does not remain in silence when challenged by a member of new COP: 
BETTY: Usually... initially I did not say anything 'back'. Now, I say 'something back'.

... In the beginning I did not have, did not master the language, because you... when you are nervous, to speak in another language, words disappear.

CHRISTINE: Of course.

BETTY: And... I know that when I argue, my English gets worse, because I am nervous.

We can see through BETTY's words how she clearly is now able to make a statement about her position as a new member of this community. Surprisingly, BETTY, in the continuation of the same conversation, brings up a new and what she sees as a positive perspective of being a Brazilian immigrant opposing to being from another country, as it can be observed in her words:

\footnotetext{
CHRISTINE: Now tell me a little then, about this positive aspect then, the fact that being a Latina, foreign, Brazilian, or even the fact that you bave a, little difficulty while interacting, when this becomes something good? BETTY: Because a lot of people, they are open to other cultures, so a lot of people when they see you are having some difficulty, either they joke about it or try to belp or when they realize you (bave) an accent and talk about Brazil, "but where are you from?" during the Olympics, everybody says "Wow, you' re from Rio".

CHRISTINE: There is always someone.

BETTY: For example, at the gym, I go to the gym, kind of, my only leisure here during the week, and then a lot of people, you know, when they knew, when they found out I was Brazilian, initially they thought I was Mexican or Colombian.

BETTY: And then, then they still bave some resistance, some, but when they find out you are Brazilian... as if Brazil were something different from everything else.
}

This way, although we can perceive BETTY still feels discrimination towards her for being an immigrant, her self-perception is that being Brazilian, she is in a more privileged status than other foreigners originated from other countries in Central or South America.

\subsection{Different sites, different identities}

As we are able to perceive through BETTY's words, her identities are in constant change, being negotiated as she tries to be accepted in her new community of practice. As an immigrant, BETTY's life is not easy and besides having to deal with her own struggles for not feeling part of the new community, for still trying to empower herself through language, her mother also reinforces this feeling of low self-esteem:

BETTY: I think that (sobs), as I said, I have never suffered prejudice in Brazil, I was never (part of minority in Brazil, thanks God I come from, I come from a family, as you bave just said, I was raised only by my mom, my mom did everything she could for me and for my brother, I have always been loved. Anyway, and, for me it was a shock to be on the other side. For me it was a shock to be part of the minority. For me it was a shock ( ) that I was nobody, that I looked around and I had nobody.

.... I, you know? What I take from this is that I value, very much, much more than I already did value my life in Brazil. 
... My mom bas always said, you bave a promising perspective of life, you can return, you can finish college, you can apply for a job, bere you are a person, in the United States you are nobody.

Once we understand the process of building an identity as a life time work, always ongoing and never ending, we also have to realize that it is a situated process where contextual factors interplay in its performance. Building herself a positive and strong identity through language learning, in this case, through the mastering of a good competence in English, has not automatically made the COP embrace BETTY as one of their own. Not only BETTY was aware of that but also her mother which, even though in a non-tangible way, is pointing to an old debate about language and national identity (HOBSBAWM, 1990; DUCHÊNE \& HELLER, 2012; RICENTO, 2015).

The same feeling does not haunt JULIA's daily interactions. Indeed, concurring with Wenger's framework of identity formation (1998) building oneself a positive and strong identity does not lie only in the way one speaks to another or in what one think about another but rather in the way one live and perform its own identity. In the author's own words "identities are formed amid the tension between our investment in the various form of belonging and our ability to negotiate the meanings that matters in those contexts" (WENGER, 1998, p.188). This is how JULIA's seems to proceed in her day-to-day experiences telling us that as her language competence grows, it also grows her confidence in navigating through different sites and interacting in the social world reinforcing thus her emergent bilingual identity:

JULIA: You know, I like to chat... a lot... I am very easy to make friends. And over there, people use to do a
lot of research, they like it and then they would come to me and ask: Julia, can I do this research with you? And
I replied... look my English is not very good but if I can give the answers, we can do it. And with that we started
a friendship.
There was also a War Museum that I liked to go and there was this old man, Mister Tony, and old people usually
like to chat ... a lot... and then once in a while I go there, and we became friends. At the beginning, I didn't know
bow to say "war" in English, but I've learned with bim. I made a lot of friends because I could understand more the
language and I could adapt.

It seems that JULIA is, at the same time, investing in her language learning and negotiating meanings with her entourage believing that she can learn, thus she can participate in this COP, identifying herself with its members, engaging with them, becoming friends with them.

As a last remark, we can notice how BETTY's experience is somehow reinforced by members of the new community of practice. This way, ideas which she had previously formed in her imagined community seem to once more fall apart due to the way some of these new members see her and make her reframe her 
identity in a negative manner. While describing a Thanksgiving family gathering, one of the few times which BETTY was invited to have a meal with the host family, she describes comments made by the husband and father of the host family, also her employer:

BETTY: The busband makes real racist comments concerning immigrants. 'Oh, these bunch of immigrants come bere, and then they want to enroll their children in my kids' school'. And then, 'my daughters bave to stay in that packed room and do not bave the same attention they deserve'.

CHRISTINE: Hum, bum.

BETTY: This kind of comment, and then you realize... Speaking to me, really? For a moment they forget you are an immigrant.

As it can be observed through BETTY's voice, there is a feeling of sadness in which she empathizes with the existent prejudice against immigrants in the U.S. Again, although actually BETTY was not in the status of an immigrant since she was on student's visa through an aupair program, she saw herself as one, and as a result she seems to empathize with immigrants' situation in the U.S. An immigrant who was not acknowledged for same identities in her community of origin, but as a person who was not entitled to exercise the same rights of an American citizen, as for example, school public education as the head of the family (her employer) himself emphasized.

Towards the end of the interview BETTY makes a recap of the experience as an Aupair.

CHRISTINE: And what lesson are you taking from this... From all this experience? I can see your English bas empowered you, right? English was...

(BETTY laugbs)

CHRISTINE: A great advantage, now you fight back.

(BETTY starts crying)

BETTY: I am going to cry... What I take from this is that, I was one person... I arrived as someone and I'll leave as some else, completely different...

Through BETTY's words we can clearly see how she pinpoints her identity transformation. Interesting to notice the researcher reinforces BETTY's own words saying now you fight back (although BETTY's original words were now I say something back) showing her own empathy towards BETTY's situation, who now seems to end her experience as a different person, on the other hand, stronger, more autonomous and aware of her power to not only change herself but also the ones around her.

On a different note though, JULIA also comments on her own experience, enhancing how the learning of an additional language on the move has shaped new features for her identity. 
JULIA: This experience bas changed my life because when you bave a second language you become a more independent person. Today I know that you can send me to China, Japan, wherever, because I know I will be able to communicate and do what I have to do. When you acduire this new competence, it makes you a more versatile person within your field of expertise and that is exactly what I bave always tried to achieve since I was a kid.

BETTY and JULIA are example of sociocultural autonomy development through agency and empowerment triggered by language learning. Despite some similarities - BETTY and JULIA were on a student's visa status - their differences - BETTY went abroad through an aupair program and JULIA was enrolled in an academic mobility program. - impacted on their process to rethink their identities. Above all, language learning has significantly paved their path to stronger, empowered and autonomous identities.

\section{CONCLUDING REMARKS}

This paper was based on two studies in which issues on identity, empowerment, agency, and overall autonomy, through language, were addressed. Illustrated by the narratives of BETTY and JULIA, our study shows that building or reframing oneself an identity might be an attitude driven by language learning. No matter how important mastering a language might be, though, identities are complex structures exposed also to social, cultural and historical processes such as gender, race, social class, ethnicity, sexual orientation and even language proficiency, naturally, capable to impact in identity formation (NORTON \& TOOHEY, 2011). As processes entailing relations of power, they are of paramount importance in the process of reframing participants' identities. As Fairclough and Wood teach us: (2002, p. 368)

Discourse practices can have significant ideological effects, they can be decisive, they can assist in producing and reproducing unequal power relations (for instance) between social classes, women and men, cultural or ethnic majorities and minorities, through the manner that objects are represented and people are situated.

Build oneself an identity is at the same time an individual and a relational experience, a social and a contextual experience (WENGER, 1998). As such, BETTY and JULIA's experiences entail relations of power and imply a negotiation about the limits of one can go. Through language learning, BETTY and JULIA had to exert their agency and their autonomy and negotiate their access to the new COP where they were both living.

To both learners, however, language learning should be understood as only part of the equation since "the social position of different language users, rather than their linguistic repertoires impact on how their linguistic practices are heard" 
(FLORES \& ROSA, 2015, p. 162), which is the case when BETTY endure linguistic, social and racial (in the sense of her ethnicity and foreign identity) stigmatization. JULIA, on the other hand, benefits of her status of foreign student, of "temporary migrant" and regardless of her language proficiency, empowers herself building a confident identity in the community where she was engaged.

As researchers, we should take into account that "through human agency, language learners who struggle to speak from one identity position may be able to reframe their relationship with others and claim alternative, more powerful identities from which to speak, read or write, thereby enhancing language acquisition" (NORTON, 2012).

Both JULIA and BETTY seem to reframe their multiple identities, so that they adapt and readapt to the new COPs, in which they have emerged. It seems they are aware they have transformed and reshaped their identities in a way they are not the same when they return to their original CPOs. Sociocultural interactions and language learning have intensively acted in the process of identity construction of these two young women and whether they have felt empowered or disempowered by some people, they have also been legitimated by others.

\section{REFERENCES}

ARCHANJO, R. (2015) Globalização e Multilingualismo no Brasil Competência Linguística e o Programa Ciência Sem Fronteiras. Rev. bras. linguist. apl., vol.15, no.3, p.621-656. ISSN 1984-6398

ARCHANJO, R. (2016) Saberes sem Fronteiras: Políticas para as migrações Pósmodernas. DELTA, vol.32, no.2, p.515-541. ISSN 0102-4450

ARCHANJO, R. (2017) Moving Globally to Transform Locally? Academic mobility and language policy in the Brazilian context. Language Policy, v.16, nº 3, p. 291-312. https://doi.org/10.1007/s10993-016-9408-0

ANDERSON. B. (1983/2006) Imagined Communities: Reflections on the Origin and Spread of Nationalism -revised edition. New York: Verso.

BAUMAN, Z. (2004) Identity: Conversations with Benedetto Vecchi. Cambridge, UK: Polity Press.

BAKHTIN, M. (1981) The Dialogic Imagination: Four Essays by M. M. Bakbtin. Austin: University of Texas Press. 
BAKHTIN, M.; VOLOCHINOV, V.N. (1929/2006) Marxismo e filosofia da linguagem. Tradução Michel Lahud e Yara Frateschi Vieira. 10. Ed. São Paulo: Hucitec, 196p.

BAUMAN, Z. (2005) Identidade: entrevista a Benedetto Vecchi. Rio de Janeiro: J. Zahar.

BLOMMAERT, J. (2006) Language ideology. IN: T. Todorov (Ed.) Handbook of Language and Linguistics. Vol. 6, Elsevier, p.510-523.

BOURDIEU, P. (1991) Language and symbolic power. Cambridge, MA: Harvard University Press.

BOURDIEU, P. (1977) The economics of linguistic exchanges. Social Science Information. 16.6, p.645-668.

DARVIN, R. \& NORTON, B. (2016) Investment and Language Learning in the $21^{\text {st }}$ Century. Language et Société, 157 (3), p. 19-38.

DE FINA, A. (2016) Linguistic practices and transnational identities. In: SIÂN PREECE (Ed.) The Routledge Handbook of Language and Identity. Routledge, p.163-178.

DUCHÊNE, A. \& HELLER, M. (2012) Language in Late Capitalism: Pride and Profit. New York: Routledge.

FAIRCLOUGH, N. (2001) Discurso e mudança social. Brasília: Editora UNB.

FAIRCLOUGH, N. \& WODAK, R. (2002) Análisis crítico del discurso. In: El discurso como interacción social. Estudios sobre el discurso II: una introcucción multidisciplinaria. Barcelona, Espanha: Gedisa, p. 367-404.

FLORES, N. \& ROSA, J. (2015) Undoing Appropriateness: Raciolinguistic Ideologies and Language Diversity in Education. IN: Harvard Educational Review Vol. 85 No. 2.

HALE, C. (2012) Power, Position and Autonomy: Student Conflict in a Communicative Language classroom. IN: Teachers College, Columbia University Working Papers in TESOL \& Applied Linguistics, Vol. 12, No. 1, Columbia University, Tokyo, p. 1-17.

HALL, S. (1992) "New Ethnicities" in 'Race'. Culture and Difference, DONALD, J. \& RATTANSI, A. (Eds.), 252-259. London, California and New Delhi: Sage Publications with the Open University.

HUNTER, J. \& COOKE, D. (2007) Through autonomy to agency: Giving power to language learners. IN: Prospect Vol. 22, No. 2 2007. Access at View at http://www. 
ameprc.mq.edu.au/_data/assets/pdf file/0019/67060/Prospect_22,2 5 Hunter. pdf

HOBSBAWM, E. (1990). Nations and nationalism since 1780. Cambridge, UK: Cambridge University Press.

LAVE, J. \& WENGER, E. (1991) Situated learning: Legitimate peripheral participation. New York: Cambridge University Press.

MAKONI S. \& PENNYCOOK, A. (2006) (Eds). Disinventing and Reconstructing Languages. Clevedon, Avon: Multilingual Matters.

McKINNEY, C. \& NORTON, B. (2008) Identity in language and literacy education. In: B. SPOLSKY, B. \& HULT, F. (eds.), The bandbook of educational linguistics. Malden: Blackwell, p. 192-205.

MERCER, K. (1990) Welcome to the jungle. In: RUTHERFORD, J. (Ed.) Identity, community culture, difference. London: Lawrence and Wishhart.

MOITA LOPES. L.P. (2006) Uma linguística aplicada mestiça e ideológica: interrogando o campo como linguista aplicado. In: MOITA LOPES, L. P. (Org.). Por uma linguística aplicada Indisciplinar. São Paulo: Parábola, p. 13-43.

NICOLAIDES, C. (2017) Agency and empowerment towards the pursuit of sociocultural autonomy in language learning. In: NICOLAIDES, C. \& MAGNO E SILVA, W. (Orgs.). Innovations and Challenges in Applied Linguistics and Learner Autonomy. São Paulo: Pontes Editores, p.19-41.

NORTON, B. (2000) Identity and language learning: Gender, etbnicity and educational cbange. Harlow, England: Longman/Pearson Education.

NORTON, B. (2012) Identity and language learning: extending the conversation. 2nd ed. Bristol: Multilingual Matters.

NORTON, B. (2010) Language and Identity. In: HORNBERGER, N. \& McKAY, S. (Eds.), Sociolinguistics and language education. Clevedon, UK: Multilingual Matters.

NORTON, B. (2013) Identity and language learning: Back to the future. TESOL Quarterly, $50(2), 475-479$.

NORTON, B. \& TOOHEY, K. (2011) Identity, language learning, and social change. Language Teaching, 44, 4, 412-446. (State-of-the-Art Article). 
OXFORD, R. L. (2003) Toward a more systematic model of L2 learner autonomy. In: PALFREYMAN, D. \& SMITH, R.C. (Eds.) Learner Autonomy across Cultures: Language Education Perspectives. Basingstoke: Palgrave Macmillan, p. 75-91.

PAVLENKO, A. \& NORTON B. (2007) Imagined Communities, Identity, and English Language Learning. In: CUMMINS J. \& DAVISON C. (Eds) International Handbook of English Language Teaching. Springer International Handbooks of Education, vol 15. Springer, Boston, MA.

RICENTO, T. (2015) Language Policy and Political Economy: English in a Global Context. New York: Oxford University Press.

VERTOVEC, S. (2007) Super-diversity and its implications. Ethnic and Racial Studies, v.30, n.6, p.1024-1054.

VYGOTSKY, L.S. (1985) Thought and Language. Cambridge, MA: The M.I.T. Press.

VYGOTSKY, L.S. (1991) A formação social da mente. São Paulo: Martins Fontes.

WEI, L. \& HUA, Z. (2013) Translanguaging Identities and Ideologies: Creating Transnational Space Through Flexible Multilingual Practices Amongst Chinese University Students in the UK. Applied Linguistics 34/5. Oxford University Press, p. $516-535$.

WOODWARD, K. (2002) Understanding Identity. New York: Oxford University Press.

WENGER, E. (1998) Communities of Practice. Cambridge University Press: New York, 18th printing, 2008.

Recebido: $16 / 11 / 2018$

Aceito: 10/03/2019

Publicado: 29/03/2019 